\title{
THREE VOICES OF SOCIO-LEGAL STUDIES
}

\author{
Malcolm M. Feeley*
}

\section{Introduction}

The connection between law and contemporary social science emerged as a consequence of the quest for social reform. As law became more instrumental, it also became more empirical, more concerned with policy. For this process, it turned to social science. Social science complied and has become an adjunct to law in the quest for solving social problems. As this partnership has developed, the relationship between law and social science has matured. Not only has social science sought to educate and influence law, it has also incorporated law into its own disciplinary concerns. Furthermore, the field of socio-legal studies may be on the verge of establishing itself as a separate and distinct discipline, independent of the practical concerns of law.

The scholarly intersection of law and social science - or socio-legal studies, as I shall call it - now speaks with at least three voices addressed to at least three audiences. It speaks as policy analysis, a handmaiden to law. It also speaks in the traditional language of the social sciences. Thirdly, it may be gaining a voice of its own, reflecting a belief that law is a distinct form of ordering that merits its own position among the scholarly disciplines, separate from both scholarly fields and the professional concerns of law. At their core, each of these enterprises entails a distinct voice, a distinct audience, and a distinct agenda.

After tracing the recent history of the relationship between law and the social sciences in the United States, this article identifies three different voices in which socio-legal studies speak and their three somewhat different audiences. The discussion is both tentative and partial. The developments I examine are far from complete. None of the three distinct voices I identify has yet fully matured. None of the audiences has solidified into a distinct grouping. Moreover, it is possible that socio-legal concerns about the efficiency and efficacy of law, or at least some types

* Claire Sanders Clements Professor of Jurisprudence and Social Policy Program, Boalt Hall School of Law, University of California at Berkeley. During the writing of this article, the author was a Fellow at the Center for Advanced Study in the Behavioral Sciences. 
of these concerns, will simply be assimilated into legal scholarship itself, just as in the 1930s legal realism and, more recently, critical legal studies disappeared as separate enterprises as they were assimilated into mainstream legal scholarship. Similarly, the established disciplines may lose interest in law and move on to other things. It is also possible that the most ambitious enterprise of all - the establishment of law as a separate social science discipline or field - will not take root. Thus, the entire process remains problematic, if not precarious. Still, these developments are distinct, and it should be useful to map them out.

\section{The Emergence of Socio-Legal Studies}

Until fifty years ago, the study of law as the object of social science inquiry, though not unknown, was at best intermittent and marginal to academic social science and legal scholarship. The sociological (broadly defined to include all of the social sciences, including psychology and economics) study of law was limited to the occasional sociologist, historian, economist, or law professor, who had strayed far from the mainstay or central focus of his or her scholarly community. Some of these exceptions are notable. At the turn of the twentieth century, Emile Durkheim, the great French sociologist, focused on law in his search for understanding a society's moral sentiments and established an important but short-lived school in which law was a major focus. ${ }^{1}$ More generally, the social bases and consequences of law have always been of concern to a handful of idiosyncratic scholars, such as Sir Henry Maine, Rudolph von Jhering, Oliver Wendell Holmes Jr., Benjamin Cardozo, Max Weber, Eugene Erlich, John R. Commons, Willard Hurst, and a scattering of other anthropologists, sociologists, economists, lawyers, and historians who saw law as an important and distinctive form of social ordering.

There are some institutional exceptions to this account as well. For well over one hundred years, criminology has focused on deviance and law-conforming behavior, though even here criminal law has not been a distinct focus. This literature is too voluminous to canvass here. There is also a long tradition of legal history. Although much legal history takes the form of the genealogy of legal doctrine, there is a small,

1 For a sustained analysis of Durkheim's work, see Roger Cotterrell, Emile Durkheim:

Law in a Moral Domain (Edinburgh, Edinburgh Univ. Press, 1999). 
separate tradition that incorporates the study of law into the field of history. ${ }^{2}$ More recently, in the early 1900 s on the Continent, in England, and in the United States, there were movements to foster "sociological jurisprudence" and "legal realism" - both of which will be examined briefly below. Still, with these and a handful of other notable exceptions, social science and law were not joined together in any deeply institutionalized way until the 1960 s. Since then, the connection has deepened and broadened, and, as I have suggested, socio-legal studies may be emerging as a distinct discipline.

It is impossible to identify all the causes for the growth of socio-legal studies over the past 50 years. Indeed, there is probably no clearly identifiable set of sources. A variety of developments at different times, in different places, and for different reasons have coalesced to foster the contemporary law-and-social-science movement. There are, in all likelihood, several histories, not just one. ${ }^{3}$ Yet, there are some broad contours in this development that would be widely agreed upon. The movement's roots are traceable to nineteenth and early twentiethcentury legal scholarship on the Continent, as legal formalism gave way to an instrumental understanding of law, and the modern welfare state began to blur the lines between law and policy. On the whole, the movement resulted from the expansion of the role of the state and recognition that the modern administrative state governs through law.

Sir Henry Maine, Ancient Law: Its Connection With the Early History of Society and its Relation to Modern Ideas (London, Dent Reprint [1861], 1977) may be the most conspicuous such study. Written after a career of judicial service in India, it employed an evolutionary scheme to compare then contemporary Hindu law in India with feudal and modern law in England. 25 years later Oliver Wendell Holmes published The Path of the Law (New York, Dover Reprint [1881], 1991) which distinguished itself from much legal scholarship with its claim that "the life of the law is experience and not logic." He sought to anchor developments in common law principles to changes in social thought and practice. At about this same time Fredrick Pollock and F.W. Maitland were in the midst of their path-breaking studies of English law that located their work in a branch of social history rather than the more traditional legal history. See, e.g., Fredrick Pollock and F.W. Maitland, History of English Law before the Time of Edward I (1895, 1968 ed.), 2 vols.

3 This is most clearly seen in law and economics. Although I include this rapidly growing field in Socio-legal studies, many others would not. See, e.g., Richard Posner, "The Sociology of the Sociology of Law: A View from Economics" (1995) 2 European J. Law \& Econ. 265-284; and Bryant Garth and Joyce Sterling, "From Legal Realism to Law and Society: Reshaping Law for the Last Stages of the Social Activist State" (1998) 32 Law \& Society Rev. 409-472. I will return to this issue in the text below. 
The state's reliance on the law to govern is not a new phenomenon. As long as states have taken responsibility for preventing blood feuds, collecting taxes, and providing even rudimentary administrative services, they have turned to law as a form of social control. But the dramatic growth of the modern administrative state in the late nineteenth century is significant because it wholeheartedly embraced an instrumental view of law. According to this view, law cannot be captured by a concern with tradition, with justice, or by the idea of a command of the sovereign. Rather, it is a mélange of policies articulated by any number of authoritative sources, legislators, administrators, and judges. In the administrative state, regulatory law is unabashedly public and instrumental. Law and policy merge; law is no longer to be regarded as a sphere separate from the state or as a binding set of principles emanating from natural justice whose origins are independent of the state. The joining of law and modern social science is rooted in this recognition.

The reception of the administrative state, and the replacement of a conception of law as an expression of natural justice with an instrumental conception, varied widely in time and place. Perhaps because the modern positive state emerged much earlier and more gradually on the Continent, and opposition to it took a more openly political form, the debate there on the rise of administrative law was conducted in terms more overtly political than legal. In contrast, in England and especially the United States - perhaps because of the combined importance of the appeal to rights and the common law tradition - the debates precipitated a crisis in law as well as politics. Nevertheless, the outcome was much the same everywhere. Instrumentalism triumphed over law-asjustice or law-as-command; law came to be seen as a form of sociological engineering.

With the triumph of instrumentalism, it was natural enough to call on experts of the human sciences to help shape the new administrative state and help determine if it was functioning efficiently and effectively. This collaboration between law and the then new and emerging human sciences was eagerly embraced by the earliest champions of this new conception of law. Its first philosopher was Rudolf von Jhering, who, writing for a European audience in the late nineteenth century, argued that modern law was the means by which social interests could be coordinated and receive expression in public policy. ${ }^{4}$ Jhering implied

4 Rudolph von Jhering, The Struggle for Law, 2nd ed. (Chicago, Calaghan, [1872], 1915) 1. 
that the law needed to turn to those with specialized skills to determine these interests. This argument was seized upon and developed by Harvard Law School professor Roscoe Pound, who coined the term "sociological jurisprudence" to describe the self-conscious effort to systematically tailor the law to address social problems. ${ }^{5}$ Pound was a sort of latterday Bentham, who argued that since law was the resultant of a variety of interests, these interests should be systematically ascertained and collated through the techniques of social science.

Pound wrote at the height of the Progressive Era and reflected its confidence in professional expertise. In tune with his times, Pound pressed his colleagues to develop skills in the newly established social sciences - psychology, sociology, economics - and to join forces with those trained in these fields so that lawyers would be equipped to understand and solve the problems of the modern industrialized society. Pound himself did much to realize his vision of sociological jurisprudence. He participated in a number of large-scale data collection projects describing the operations of criminal courts in several large American cities and used these findings as the basis for formulating proposals for reform. As dean of Harvard Law School, he brought economists into the faculty to deal with anti-trust issues and criminologists to deal with issues of delinquency, and more generally was a tireless promoter of social science expertise among his law school colleagues and associates.

In the United States, the Depression and the New Deal accelerated the trend toward using social science in law. Indeed, even before the New Deal, fierce resistance within the legal establishment to the modern welfare state led some legal scholars to set about rethinking the tasks of law and the nature of law itself. A disparate group of law professors, self-proclaimed "legal realists," were unrelenting in their attacks on the courts, which had a long history of declaring progressive legislation unconstitutional or interpreting it narrowly. These legal realists challenged judges who argued that they had no choice but to follow long-standing precedents. ${ }^{6}$ Pound and his European colleagues had been thinking largely in terms of legislation and administrative directives. In contrast, this newer group of American "realists" focused

5 Roscoe Pound, "The Need for a Sociological Jurisprudence" (1907) 19 The Green Bag 607-615; "Law in Books and Law in Action" (1910) 44 American L. Rev. 12-36; and Social Control through Law (New Haven, Yale Univ. Press, 1942).

6 For one account of some of the developments in legal realism, see Laura Kalman, Legal Realism at Yale: 1927-1960 (Chapel Hill, Univ. of North Carolina Press, 1986). 
almost exclusively on judicial decision-making and were responding to a conservative federal judiciary that systematically declared progressive legislation unconstitutional. Caricaturing the conceptions of legal reasoning of the old-guard judges as "mechanical jurisprudence," the legal realists drew on modern psychology and philosophy to buttress their claims that legal rules are inherently ambiguous and open to multiple meanings and that law is socially contingent. But the import of their efforts was much the same as Pound's: to advance a more fluid and instrumental understanding of law that was in tune with the times. As their ideas about the merging of law and policy gained adherents, the relationship between law and the social sciences was strengthened. Increasingly, realists invoked empirical findings in the social sciences to support their claim that facts and legal rules are ambiguous and socially contingent. ${ }^{8}$

Thirty years after the Great Depression, the activism of the $1960 \mathrm{~s}-$ the quest for racial justice, the rights revolution that sought to shore up the administrative state, and the quest for social change through law - reinvigorated and expanded the New Deal agenda and the realists' claims that law is policy. Here, too, social science was enlisted as the handmaiden of law to determine what worked and what didn't. ${ }^{9}$ However, this time, the connection was institutionalized in ways it had not been before. Social scientists were appointed to law faculties, foundations supported the establishment of programs in law and social science, government-sponsored evaluation research flourished to assess the impact of legal reforms, and missions were sent overseas by the United States State Department to promote social development through law. ${ }^{10}$

7 The phrase was coined earlier. See, e.g., Roscoe Pound, "Mechanical Jurisprudence" (1908) 8 Columbia L. Rev. 605-623.

8 The most famous "fact skeptic" is Jerome Frank, Courts on Trial (Princeton, Princeton Univ. Press, 1949).

9 Several well-known anthologies on law and social science tend to focus, though not exclusively, on legal effectiveness studies. See Lawrence Friedman and Stewart Macaulay, Law and the Behavioral Sciences (Indianapolis, Bobbs-Merrill, 1969); Wallace Loh, Law and Social Science (New York, Russell Sage Foundation, 1983); Joel Grossman and Mary Grossman, Law and Change in Modern America (Pacific Palisades, CA, Goodyear Publishing, 1971); John Monahan and Laurens Walker, Social Science in Law (New York, Foundation Press, 1989).

10 For a self-reflective retrospective on the law and development movement by two participants, see David Trubek, "Scholars in Self-Estrangement: Some Reflections on the Crisis in Law and Development Studies in the Unites States" (1974) Wisconsin L. Rev. 1062-1102. 
All this led to the first organized and self-conscious effort by social scientists to establish themselves, at least on their own footing, if not on equal footing with law. This occurred not only because of the expansive optimism of the day, but more particularly because the 1960 s was a period of rapid expansion in higher education, especially in the social and policy sciences. Universities in the United States - and elsewhere - were awash with money. New universities were founded, and a variety of new programs developed. All this was aided by the disruptions at universities in 1968, and in the years that followed. Among the long list of complaints in this student-initiated movement was the charge that the traditional university curriculum was "irrelevant." University administrators from Berlin to Berkeley responded by modernizing the curriculum and making it more socially relevant. Law and social science was well-positioned to take advantage of this; it gained a foothold in the university, both in law schools and in free-standing law and society programs.

There probably is no one single act that can be identified as the beginning of this new socio-legal studies movement, but one might reasonably point to the establishment of the Law and Society Association in 1964 in the United States and of its journal Law and Society Review two years later as foundational events. ${ }^{11}$ For the first time, there was a separate organization and separate journal dedicated to the study of law that was directed not at an audience of lawyers or judges or policy makers, but primarily to social scientists writing about law as a social phenomenon. ${ }^{12}$ This development institutionalized law and social science in a new way. Although it has not spoken with a single voice, the

11 For a brief history of the law and society movement, see Garth and Sterling, supra n. 3.

12 Even this claim was initially contentious. The questions, "Who is the audience?" and "What is the purpose?" of the new enterprise were present and debated at the outset. Volume one, number one of the Law and Society Review featured a vigorous exchange between law professor Karl Auerbach and sociologist Jerome Skolnick, who staked out quite different positions. Skolnick argued for a distinct social science of "legality," while Auerbach held forth for what I have termed the "handmaiden" approach. The agenda is to be set by law, social science is to gather and assess the facts. See Karl Auerbach, "Legal Tasks for the Sociologist" (1966) 1 Law \& Society Rev. 91-104; Jerome Skolnick, "Social Research on Legality: A Reply to Auerbach" (1966) 1 Law \& Society Rev. 105-110. A manifesto a few years later that rejected all policy and normative concerns was expanded upon in Donald Black, "The Epistemology of Pure Sociology" (1995) 20 Law \& Social Inquiry 829-870. 
Association and its journal did establish socio-legal studies as an enterprise distinct from legal scholarship, on the one hand, and the traditional concerns of the established social science disciplines, on the other. The result has been a cacophony of voices. Some have pursued legal policy issues; others have focused on law in an effort to enlarge the understanding of their own disciplines; and still others have promoted the idea that socio-legal studies is a field or discipline in its own right. In addition, more recently, some socio-legal scholars have embraced the cultural turn in the humanities and social sciences.

Despite this near chaos, the law and social science movement has thrived. Throughout the English-speaking world, in Europe, and elsewhere, a great many separate socio-legal programs in colleges and universities have been established, as well as numerous journals of law and social science, and national and international associations. By any measure, socio-legal studies as a distinct form of scholarship has gained a position in the larger scholarly community. The field is still not on a par with economics, psychology, political science, or sociology, but it may have achieved a standing akin to comparative religion, comparative literature, classics, and any number of other smaller disciplines or fields. And it is still growing. Without a doubt, "law and economics" has been the most successful sub-field in this enterprise. It now boasts a dozen or so specialized journals worldwide, and the lead articles in law reviews everywhere regularly consist of law and economics scholarship. Indeed, the founder of modern law and economics, Ronald Coase of the University of Chicago, received a Nobel Prize, as have Gary Becker and others who are connected with the field.

As I suggested at the outset, it is probably not possible or helpful to speak of "law and social science" in the singular as if there were a common understanding and approach. Rather, one must appreciate the distinct (though admittedly often overlapping) voices of those speaking quite different languages. In the section below, I shall examine three distinct voices of and separate audiences for socio-legal studies.

\section{Three Voices of Socio-Legal Studies}

\section{A. Socio-Legal Studies as Policy Science}

If law is instrumental - if it is a means to an end - then law needs help in designing its means and evaluating its effects. Given this view, 
the collaboration between law and social science is both obvious and necessary. In the United States, at least, the social sciences emerged as the "applied" human disciplines, offering systematically gathered evidence and theoretical insights to help solve concrete social problems. Psychology promised insights to cope with the conditions of modern society. Sociology and social work emerged to address problems of industrialization, urbanization, immigration, and stratification. Economics sought to explicate commercial practices in order to help understand and manage economic forces. Political science offered the science of public administration for the growing administrative state. From the outset, the social sciences have been applied, problem-solving disciplines. The collaboration between law and social science is, therefore, a natural consequence of instrumentalism in law and the growth of the applied human sciences.

Furthermore, there is a similarity in form between legal scholarship and applied social science. Both proceed by identifying problems and then proffering solutions. Anglo-American legal scholarship incorporates legal scholars writing in law reviews to inform decision-makers, almost always judges, of the proper course of action they should take. ${ }^{13}$ The standard law review article consists of three parts. A doctrine, rule, or principle is stated and examined for purpose and coherence. The author then demonstrates that this doctrine is inadequate: either there are too many exceptions or changing circumstances have made it outdated so that it cannot account for enough of observed practice to warrant retention. Finally, the author proposes a solution: revision of the rule, a new rule, subdivisions within the existing rule, and the like.

13 There is, of course, an "as if" quality to this enterprise. I do not mean literally that legal scholars write only for judges and lawyers, or that only judges and lawyers read the work of the legal scholars. Indeed, if truth be told, virtually no one reads their work. My point here is that they write as if they were addressing an audience of judges or lawyers, i.e., those who have it in their power to effect the sorts of changes advocated by the authors. This form is itself quite traditional, but it is also anachronistic since the style is more appropriate to the nineteenth century Anglo-American legal system than modern law, which is developed not by judges but by legislatures and administrative agencies. Despite their zeal for reform, Anglo-American law professors have not yet located the primary sources of modern law. Needless to say, there are obvious and important exceptions to this. Nevertheless, I stand by my generalization; I invite skeptical readers to pick up a volume of a recent English or Australian or American law review at random and page through it. I wager that somewhere between 65 and $90 \%$ of the articles fit the form I have described above. 
The handful of articles that do not fit this format is mostly addressed to legislators rather than judges.

Legal policy research follows a similar format: first, the goal or objective of a particular provision in the law (for example, a statutory provision, court ruling, doctrine) is stated; evidence is then presented to show that compliance or impact differs from what was anticipated; finally, suggestions are offered regarding ways to bridge the gap between practical and theoretical law (or, if the judgment is that the law is out of date, perhaps, vice versa) ${ }^{14}$ This is the basic form that most studies in law and social science adopt. ${ }^{15}$

\section{The Struggle for an Independent Socio-legal Studies}

Some social scientists were not content with their role as handmaidens, and they developed their own agendas. They began by anchoring research in questions posed by their own disciplines, rather than those posed by the law, and began seeking explanation rather than - or in addition to - ways to improve legal effectiveness. This reaction has taken two primary forms: the effort to account for or explain the "gap" between legal aspiration and actual practice - the law in the books versus the law-in-action - and the movement to foster a "consumer" perspective that looks at law from the "bottom up" rather than from the perspective of the lawgiver or authority. Both these developments have flourished, and together they constitute the overwhelming body of empirical research of the socio-legal studies field. I shall briefly explore both of these developments below.

However, in the social sciences, as in mechanics, there has been something of an equal and opposite reaction to such legal policy analysis. From the outset, there has been a desire to establish a separate agenda for socio-legal studies. This reaction has taken two forms: the

14 Many have noted the even closer affinity between traditional doctrinal legal scholarship and economics. In contrast to the inductive approach of most social sciences, both legal scholars and economists are deductive. Both begin with a few basic principles, use them to construct a model, and from there deduce expected consequences. Furthermore, neither field is especially empirical.

15 See, e.g., Friedman and Macaulay, supra n. 9; Grossman and Grossman, supra n. 9; Loh, supra n. 9; Monahan and Walker, supra n. 9. 
movement to foster a less policy-oriented project by seeking to explain or account for the "gap" between legal aspiration and practice and the movement by disillusioned liberals or radicals to invert the concerns of policy-related research and foster a consumer or victim perspective rather than a supplier or perpetrator perspective.

\section{Gap Studies ${ }^{16}$}

As law and social science studies developed, social scientists began to address each other, as well as their legal and policy audience (this may perhaps be due to the fact that the legal audience proved fickle and did not listen). For a number of reasons, applied policy research has not been sufficient for many university-based researchers. Policy research asks, "What works?" or "How can the policy be made more effective?" The more theoretically inclined scholars want explanation. They ask, "Why?" There is a fine line between "theoretically informed" and "applied" research, and indeed, the distinction may entirely collapse upon itself. ${ }^{17}$ Although the quest for "explanation" does lead to a distinct style, the structure of analysis remains much the same: legal aspiration is contrasted with actual practice as a first step toward accounting for the "gap." However, rather than dwelling on ways to make the law more effective, the aim of gap research is to "explain" or "account for" the failure of law to achieve its aspiration.

Gap studies tend to follow a format familiar to students of organization theory. In classic sociology and public administration, organization studies often posit the mission of the organization, then contrast the stated mission or organizational purpose with actual practice, and set about accounting for the failure to achieve goals in terms of influences

16 For an extended discussion of the problems with "gap studies," see Malcolm M. Feeley, "Law and Social Science: A Critique and Notes on an Expanded View" (1976) 10 Law \& Society Rev. 497-525. See also David Nelken, “The 'Gap Problem' in the Sociology of Law: A Theoretical Review" (1981) 1 Windsor Yrbk. of Access to Justice 35-61.

17 This is certainly the case with the most theoretically rigorous area of socio-legal studies, the field of law and economics. Much of the more theoretically rich work in law and economies is also quite applied, and quite normative as well. 
of the environment, limited resources, and the self-interest of the organization's members. ${ }^{18}$

Such research appears to be scientific and "objective," but it can also mask normative preferences. It is often premised upon a questionable assumption, that "but for ..." a variety of factors, the organization's goals would have been more fully realized and the gap between aspiration and practice narrowed. When framed in this manner, the task of the researcher is to identify these "but for ..." impediments to success. Their identification constitutes the explanation. Although obviously insightful and useful, as an analytic explanatory scheme this approach is problematic. First, goals, objectives, purposes, and ideals of the law (or any institution) are not easily determined. Indeed, they are likely to be multiple, contradictory, ambiguous, and differentially understood. So the aim with which the reality is to be compared is likely to be elusive. What passes for the objectives of a law - a piece of legislation, court order, or regulation - may very well be the researcher's own ideas, and nothing unambiguously inherent in the law itself. Consider several constitutional issues in the United States in the last half century. Was the Supreme Court's objective in Brown v. Board of Education ${ }^{19}$ to put an end to formal dual school systems and integrate public schools in a salt and pepper fashion? Or was it unclear and even disputed among the justices who handed down the unanimous ruling? ${ }^{20}$ Were the U.S. Supreme Court's famous rulings in the reapportionment cases designed to enhance the power of "woefully underrepresented" urban residents as supporters of the litigation claimed, or did the justices simply want to establish an abstract principle of "one person, one vote"? Few, if any, rulings, let alone pieces of complex legislation, have clear, unambiguous meanings and objectives. However, even if they do, problems remain:

18 The model for this in organizational analysis was established by Philip Selznick in The TVA and the Grassroots (Berkeley, Univ. of California Press, 1949). In the law and society field, perhaps the most well-known such study is Abraham Blumberg "The Practice of Law as a Confidence Game: Organizational Cooptation of a Profession" (1967) 1 Law \& Society Rev., 15-40.

19347 U.S. 483 (1953).

20 For an example of "gap research," see Gerald Rosenberg, The Hollow Hope: Can Courts Bring About Social Change? (Chicago, Univ. of Chicago Press, 1991); and for an extended discussion and exchange regarding this matter, see Malcolm M. Feeley, "Fly Paper and Metaphors" (1992) 17 Law \& Social Inquiry 745 and Gerald Rosenberg, "Hollow Hopes and Other Aspirations: A Reply to Feeley and McConn," ibid., at 761778. 
even in an instrumentalist world, law can be understood as a proclamation of eternal verities rather than as a blueprint intended to effect immediate policies. Is the Equal Protection provision of the Fourteenth Amendment, for instance, best understood as a concrete policy objective or a statement of aspiration?

A second issue raised in gap research is that it has a relatively narrow outlook. Gap research is anchored in organizational level analysis and situates the practice in question in an organizational setting in ways that are likely to ignore influences of the environment. For instance, studies of criminal courts seek to account for the perfunctory performance of public defenders in terms of pressing caseloads, workgroup dynamics that foster friendly relations among nominal adversaries, and the like. Similarly, many studies of police behavior focus on weaknesses in command and control structures within the force. And studies of "street level bureaucracy" more generally emphasize the importance of discretionary practices of line staff and organizational constraints. Such studies can be, and often are, insightful. However, they also possess a distinct and limited perspective - organizational level analysis. A broader - social - perspective on the practice of public defenders, the operations of the criminal courts, the practices of the police, or the provision of public services more generally, might focus on issues of class and race. It might seek to understand practices in the administration of justice in any number of different settings, not solely in relation to individual or organizational factors, but in terms of social stratification.

I raise this issue not so as to criticize organizational level analysis, but to point out that much research on law-in-action has been anchored in organizational theory, whereas relatively little research has been anchored in broader concerns of social structure and culture. This preference for organizational level analysis is, I suspect, a consequence of the field's longstanding connection to policy research, and its desire to identify those factors that are amenable to controlled variation by policy makers. As policy-related research, such a focus is useful. Yet, most such research takes the "environment" as given and then seeks to determine how the organization can cope in this environment. Such research takes for granted what can (and in my view should) be problematized: how and why has the "environment" structured the organization as it has done? A social-legal analysis would aim to problematize not only the structure and behavior of the organization, but also elements in the larger environment as well. 
Still, whatever its shortcomings, "gap" research represents a distinct and different effort. The audience for such research is not judges or policymakers, but other social scientists. Its close affinity to "official" versions of facts, however, has spawned a reaction. The great growth in "gap" research paralleled the growth of more general policy-related legal studies. Both were, at least in the United States, products of the liberal optimism of the 1960s and were brought about by the civil rights revolution. As this era lost its luster, enthusiasm for change through law and for "gap" studies also faded. A new, more skeptical type of research was fostered. This movement will be described below.

\section{The Consumer Perspective}

The reaction to the conventional or gap studies culminated in what might be called research from a "consumer perspective," that is, from the perspective of the user or ostensible beneficiary of a legal policy. Advocates of this research strategy maintain that by taking the environment as a "given," gap studies accept authority and the existing political structure and are thus politically conservative. Their critique very closely mirrors the criticism of structural-functionalism that dominated the social sciences in the 1950s and 1960s. Proponents of a consumer perspective advocate a "bottom-up" research strategy, which approaches policy issues from the perspective of the consumer rather than the retailer or, more colorfully, the perspective of the "victim," not the "perpetrator."21 In a stratified world, official policy (and law) is (or may be) the problem; working for and speaking to authority is only likely to exacerbate this problem. Instead, one should listen to the voices of the voiceless, the oppressed rather than the oppressors, and conduct research that is subversive rather than stabilizing to the existing order. Others suggest that we study everyday life to determine law's importance in constituting both the self and society. That is, law plays an important constitutive role in shaping social choice and actions. ${ }^{22}$

21 See, e.g., Alan Freeman, "Legitimating Racial Discrimination through Antidiscrimination Law: A Critical Review of Supreme Court Doctrine" (1978) 62 Minn. L. Rev. 1049-1119; Kristin Bumiller, The Civil Rights Society: The Social Construction of Victims (Baltimore, Johns Hopkins Univ. Press, 1988).

22 Patricia Ewick and Susan Silbey, The Common Place of Law: Stories from Everyday Life (Chicago, Univ. of Chicago Press, 1999). 
Some of those who embrace this perspective have been criticized by other scholars for bending to the "pull of the policy audience." ${ }^{\text {"23 }}$ They argue that it is impossible to speak truth to power because power corrupts; because funding sets agendas; because top-down research makes taken-for-granted assumptions about structure, form, and privilege; and because recommendations are likely to reinforce hegemony rather than foster change. A "bottom-up" consumer perspective, they maintain, can do much to counterbalance such biases. At a minimum, it can identify the variety of ways that law intersects with and constitutes social reality. ${ }^{24}$

A host of movements in the social sciences, law, and socio-legal studies has heeded such admonitions. In law schools in the 1980s, the critical legal studies (CLS) movement sought to discredit ideas of progress, inevitability, natural development, and certainty in legal thought and emphasized the contingency of legal constructs. Some of this was accompanied by an academic version of guerilla theater in which radical scholars "trashed" conventional scholarship and near-sacred doctrines such as "neutral principles" and "reasonableness" in the law. Socio-legal scholars have been more sober and have produced important empirically-based studies from a consumer perspective. ${ }^{25}$ Similarly, feminist and critical-race theorists seek to view institutional arrangements though the eyes of women and people of color and emphasize how the biases of the powerful shape policy. In addition, post-modernist-inspired sociolegal work embraces something akin to a consumer perspective. Although it eschews generalization, much post-modern research emphasizes local knowledge and contextualized study of the lived experiences of the vulnerable in society in particular.

One of the standard objections to some of this writing is that it runs the risk of consigning itself to irrelevance. CLS research was often dismissed as nihilistic. Similarly, some consumer-perspective research that immerses itself in the micro-politics of its particular setting has also been criticized for its failure to provide a broader social framework

23 See Austin Sarat and Susan Silbey, "The Pull of the Policy Audience" (1988) 10 Law \& Policy 97-166, at 97.

24 See, e.g., the articles collected in Austin Sarat and Thomas, eds., Law in Every Day Life (Ann Arbor, Univ. of Michigan Press 1995); and Ewick and Silbey, supra n. 22.

See, e.g., Bumiller, supra n. 21. 
for understanding the behavior. ${ }^{26}$ Although some of this work may be too reactive to other research traditions or may become immersed in understanding micro-settings, on the whole, the "consumer perspective" has opened up socio-legal studies to an important and traditionally overlooked set of questions and perspectives. Whereas gap research is informed by an organizational theory that takes the environment as a given, the consumer perspective insists that the environment be problematized, that what has long been background be brought to the foreground.

\section{Law as Social Science}

It is commonplace to treat social science as the handmaiden of law, as Pound and the legal realists did, but it is possible to turn the relationship on its head. Rather than social science being an adjunct to law, some might conclude that law has been absorbed into the social sciences, has become a branch of the behavioral disciplines, public administration, psychology, or economics. Consider that traditionalists hold that law is an expression of justice. Legal rules and principles incorporate the idea of justice and the idea that conflict resolution under law should be the just solution. Many who believe in a strong version of this claim inveigh "against settlement" and decry a process of adjudication that has abandoned any authoritative declaration of justice. ${ }^{27}$ They lament the demise of law and object to its replacement, negotiation, settlement, and adjustment. If they are correct, it may be that applied social science - the policy sciences or public administration - has triumphed at the expense of law and justice. New so-called law is simply one more of the applied human sciences, whose aim is to manage, manipulate, and maximize - not realize justice.

An odd mix of scholars - traditionalist legal scholars, philosophers, post-modernist cultural critics, and assorted social scientists - might all agree with such a conclusion, though for quite different reasons. Reflecting on developments in contract law, Grant Gilmore laments the

26 See Joel Handler, "Postmodernism, Protest and the New Social Movements" (1992) 26 Law \& Society Rev. 697-732.

27 See Owen Fiss, “Against Settlement" (1984) 93 Yale Law Journal 1073-1090. See also Judith Resnik, "Managerial Judges" (1982) 96 Harv. L. Rev. 376-448. 
"death of contract." ${ }^{28}$ Reflecting on developments in tort law since the 1950 s, Henry Steiner has shown how the traditional social vision directed at unique individuals in classic tort law doctrine has given way to an approach which views the parties as representatives of groups in an assessment of "statistically predictable events," in which the objective is not justice but "managing losses" and "distributing costs." 29 Jonathan Simon and I have pointed to similar developments in the criminal process; the "new penology" focuses on "actuarial assessment of aggregate risks of danger" rather than the traditional concerns of individual intention, harm, guilt, and responsibility. ${ }^{30}$ The criminal law philosopher Michael Moore laments the in-roads the medical model has had in modern criminal law. ${ }^{31}$ More generally, any good Kantian must despair at the instrumentalism that pervades modern law, and conclude that the quest for justice has been hijacked by utilitarian thugs.

However, it is not only traditionalists longing for a lost deontological world who decry the decline of law and the triumph of "policy." Michel Foucault would agree with much of the concern presented above, though for quite different reasons. With the rise of the penitentiary, he argues, criminal law was replaced by the "disciplines" - the applied behavioral sciences - which seek to normalize through the inculcation of selfdiscipline.$^{32}$ Foucault and his colleagues focus on any number of modern institutions and practices - mental health, industrial accidents and insurance, sexuality - and here, too, argue that the dignity of the individual, acknowledged under a traditional conception of law, is wholly denigrated by a new form of "law" guided by the manipulative "disciplines."

Foucault's conception of "law" is not based on any Kantian-like link to morality. Rather, he embraces an Austinian-like view of law as "the command of the sovereign" who reacts with violence to smash those who violate his commands. He distinguishes between the absolutist, but

28 Grant Gilmore, The Death of Contract (New Haven, Yale Univ. Press, 1982).

29 Henry Steiner, Moral Argument and Social Vision in the Court: A Study of Tort Accident Law (Madison, Univ. of Wisconsin Press, 1987) 8.

30 Malcolm M. Feeley and Jonathan Simon, "Actuarial Justice: The Emerging New Criminal Law" in David Nelken, ed., The Futures of Criminology (London, Sage, 1994) 173.

31 Michael Moore, Placing Blame: A General Theory of the Criminal Law (Oxford, Clarendon Press, 1997).

32 Michel Foucault, Discipline and Punish: The Birth of Prison (New York, Vintage Books, 1979). 
limited demands inherent in traditional conceptions of law and the manipulative holistic schemes that have replaced them. The former require only obedience of the body - the latter, Foucault laments, seeks the soul. Foucault's objective is not to offer an apology for the ancien régime, but he acknowledges that it did have the virtue of exacting only obedience of the body and not surrender of the mind. You were required to bow to the sovereign, not to love him. Modern law/discipline, according to Foucault, dictates that you love your oppressor. These alternatives constitute no choice for Foucault; arbitrary command and brute force are to be preferred to modern disciplines/law.

Foucault's interest in law was intermittent; at best it was peripheral to his concerns. However, Tim Murphy draws heavily on the work of Foucault and his concept of épistime in exploring changes in the logic of government in modern societies. Murphy's central argument is that law was once central to the regulation of society and a society's own sense of self-knowledge, but that in modern societies the importance of law has been considerably diminished. Murphy describes the "escape from law" in modern societies and the corresponding loss of legal vision embodied in classical notions of law. Law, he maintains, has been displaced by the disparate, dispersed technologies of discipline of modern government, and is increasingly "irrelevant." 33 Murphy's book is perhaps the most sustained and profound analysis of the "law is dead" claim that many have asserted. What makes his analysis stand apart is not only his proclamation that law is moribund, but his charting out the new statistical "disciplines" that have come, first to absorb and then to replace law.

Space does not permit a detailed analysis of the view that law has been replaced by or been absorbed into the social sciences, or in Foucault's term "disciplines," but I do hope that I have at least outlined several versions of this powerful, unsettling claim. Certainly, there is no single coherent school of thought that maintains this position. Rather there are several quite different traditions that come to similar conclusions, often for very different reasons. But what most of these diverse views have in common is that they see classical law in categorical terms and lament the rise of the seemingly infinitely flexible, instrumental institution that has replaced it. Once law commanded, now it adjusts. Once it encompassed authority or justice, now it reflects interests and meas- 
ures statistical tendencies. Once it sought conformity of behavior, now it claims the soul. This new law is no law at all.

Perhaps the argument I have outlined above - that law has been assimilated into the applied social sciences - might seem far-fetched, at best a mixed bag of complaints by a disparate group of critics of modernity. However, there is at least one quite familiar development that lends considerable credence to this argument. The law and economics movement is generally understood to apply the insights of economics to law. There is, however, another way of explaining the relationship: law has been assimilated into economics. In economics, individuals and firms are presumed to be forward-looking and rational and are expected to behave accordingly. Economists have applied this same set of assumptions to law, thus making it possible to employ the framework of welfare economics to assess the social desirability of legal rules in the same way that it is possible to assess the actions of firms in the market or, for that matter, any other forward-looking, rational, decision-making entity.

\section{Law as a Branch of Applied Economics}

Economics is an imperialistic discipline. In recent years, it has expanded with great success into the other disciplines, including law. The law and economics movement is strong enough to suggest that law is now an applied branch of economics. Indeed, one thoughtful observer has argued that economics constitutes a new natural law for the modern age. ${ }^{34}$ Economics, David Driesen argues, provides or purports to provide a set of universal axioms about human nature that informs or can inform us as to how to structure the law and legal institutions. These axioms, he argues, meet the criteria for modern natural law in that they are general, universal, and provide a foundation for guiding specific concrete practice. Despite the natural law label, this argument underscores my point: economics provides the foundation or base, and law is, as it were, the superstructure.

34 Presentation by David Driesen, Syracuse University Faculty of Law, at a Roundtable "Toward a World Rule of Law - Contributions from Natural Law Thinking" Annual Meeting of the Law and Society Association, Vancouver, British Columbia, 30 May 2002. 
The foundation of the field of law and economics is perhaps the Coase theorem, which shows that in a world without transaction costs, the distribution of resources is invariant to the rule of law; if transactions are costless there is no need for law. But transactions, however, are not costless, and so the function of law is to impose rules that would be arrived at through bargaining in a world without transaction costs..$^{35}$ If economics is the science of understanding the rational, forward-looking behavior of individuals and firms, then rules of law and legal decision-making are every bit as much the subject matter of economics as is the market. Accordingly, law is assimilated into economics. Legal rules are designed to produce outcomes that would be reached through negotiations in a world without transaction costs. From here, it is only a small step to argue that the "mysterious science of law" is only decipherable through the "dismal science" of economics. Standards, principles, rules, precedents, procedures, and rights only make sense - or don't make sense - within this framework. With the increasing number of economists, lawyer-economists, and would-be economists on law faculties, there is some considerable persuasiveness to the claim that law has become a form of applied economics. A self-proclaimed, imperialistic science, economics may have appropriated law unto itself. Indeed, as I have suggested above, it may constitute the new natural law for the modern era.

\section{B. Law as a Central Concept in the Social Sciences}

Some social scientists have assimilated the law into broader concerns within their own disciplines. This has produced a vast and varied literature, where the law, rather than being the object of attention, is a variable, an element, or a component part of a broader scholarly enterprise. Here, too, this approach to law and social science has taken many forms. At the risk of simplification, I shall suggest there are two major forms: law as a useful example and law as a key component.

\section{Law as a Useful Example}

This idea is clear. Law provides an instance of a more general problem of some sort, and because it is concrete, public, and recurring and

35 Ronald Coase, "The Problem of Social Cost" (1960) 3 J. Law \& Econ. 1-44. 
because lawyers analyze what they do ad infinitum, it presents opportunities for wonderful examples. This development is most clearly seen in philosophy. Law provides an inexhaustible supply of examples through which such concepts as causation, responsibility, excuse, and the like can be explored. Such concepts loom large among moral philosophers, who, not surprisingly, have turned to law as a point of departure and for examples when elucidating their ideas.

What holds for moral philosophers holds for social scientists as well. Social psychologists look to law and legal settings as convenient venues for pursuing some of their own theoretical concerns. Thus, social psychologists turn to juries as loci in quo for examining the dynamics of decision-making in small groups. Psychologists examine eye-witness testimony to further their research on memory. Students of socialization study attitudes towards law and conformity to law as a way of advancing their understanding of socialization. Students of norms and moral reasoning may look at the law to see how important procedure is, as opposed to substance or outcome, in judging a collective decision-making process as fair or unfair. Students of deviance explore criminal behavior and the social construction of crime in order to advance their understanding of the causes, construction, and consequences of deviance. This list could be extended. What much of the research identified above has in common is that law and legal institutions provide examples and settings for the social scientist, whose primary concerns are elsewhere and more general and whose primary audience is within his own discipline.

However, researchers in these fields often try to speak in two voices and address two different audiences. They seek to advance knowledge in their disciplines where interest in the law might be slight or nonexistent and at the same time share their insights with the judges, lawyers, and policy makers of all sorts, as expert witnesses or as consultants who seek to put their knowledge to use as well. And, of course, some might choose careers in applied research. In the United States, there are any number of jury consulting firms staffed by social psychologists who offer advice to lawyers about the ideal composition of juries in their particular cases, or others who offer their expertise in eyewitness testimony, and the like. This sort of work blends into the applied policy research discussed earlier in this article. 


\section{Law as a Key Component in Social Theory}

Historically, law has not figured prominently in social science theories, or if it has, it has occupied some murky and ill-defined place in them. Still, law occupies a significant place in a handful of important social theories, and law is accorded some attention in an increasing number of social science theories. Let's begin with the greats: Marx, Weber, and Durkheim, but in reverse order. Of all the grand social theorists, only Emile Durkheim incorporated law as a central component of his "theory of society." Durkheim was interested in law, but only as an indicator of the form and nature of social solidarity. His project addressed the question: How do societies cohere? How are they held together? In formulating his answers, he turned to law, because it was an indicator of the "conscience collective," and, thus, was an important "independent variable" in his analysis. Law was not so much the object of his inquiry as it was part of the explanation for the problem he had posed for himself.

Law plays something of a similar role in the works of Max Weber. Weber was concerned with modernization (individualism, capitalism, and the structure of organization and modern forms of authority), the conditions that give rise to it, and the institutions that sustain it. He linked different forms of social organization and different forms of authority to a number of factors, including variable conceptions of law and legality. As with Durkheim's theories, law plays an important part in Weber's theoretical construction of society and social change, but it was a component part and one more associated with cause than effect. ${ }^{36}$

The third of these great social theorists had little use for law at all. Karl Marx barely addressed law in his voluminous writings, and when he did, he gave it short shrift. In a world shaped by the modes of production, there was no room for idealism or for the principle of legality to be a significant force. Later Marxists did address law, some of them at great length, but none save perhaps Antonio Gramsci, accorded it much of a place in Marxist theorizing. Evgeny Pashukanis, the great Soviet legal scholar in the 1920 s and early 1930 s, addressed modern law

36 Weber did not use causal language in his works, but it is clear that changes in the law were not his primary concerns and that when he identified changes in legal form, he usually did so in order to illuminate a broader and, in his view, more fundamental change in the structure or organization in society. In this sense, law for him was more a "dependent" than "independent" variable. 
at some length, but only to show that it took a commodity-exchange form and thus reflected and added nothing independent of capitalist relations. ${ }^{37}$ Law had no independent force and so could be safely ignored by social theory.

Later, in revisionist theories of Marxism, law came to occupy a significant place. In his analysis of institutions in advanced capitalist societies, Gramsci made law a significant component in his account of liberal mystification. ${ }^{38} \mathrm{He}$ argued that law is a primary means by which false consciousness is fostered. The myth of law - belief in its evenhandedness, disinterestedness, equality, and predictability - is crucial for liberal domination. It renders invisible the injustices of class and fosters quiescence in the face of exploitation. Law, he argues, pacifies.

Contemporary socio-legal scholars have offered moderate variations on this theme. Stuart Scheingold has argued that law fosters a myth of rights that is so powerful that, at least in the United States, it can blind people to overwhelming evidence to the contrary. ${ }^{39}$ Courts, he finds, can embrace causes and ideals that "politics" can negate and even destroy. Yet, the politics of rights can blind us to this destruction. Court orders can thus give the appearance of change without the reality of change. As such, they are potent instruments of the powerful. However, he does say that because the myth is so powerful, court pronouncements establishing new "rights" can be, and at times are, used effectively to mobilize segments of the mass public and thus can in fact cause substantial change. But here court rulings play, at best, only an indirect, catalytic effect. Scheingold's theme has been adopted by a number of other political scientists, some claiming that there is no evidence that court rulings have any catalytic or indirect effect, ${ }^{40}$ others arguing that they can be significant catalysts in mobilizing for political change. ${ }^{41}$ Within sociology, Lauren Edelman has elaborated on some of these themes. Her work describes how ambitious statutes and court rulings establishing

37 E.B. Pashukanis, Law and Marxism: A General Theory, B. Einhord, trans- what is the correct citation for translation?. (London, Ink Links, 1978).

38 Antonio Gramsci, Selections from the Prison Notebooks. Q. Hare and G. NowellSmith, eds. and trans., (New York, International Publishers, 1971.)

39 Stuart Scheingold, The Politics of Rights: Lawyers, Public Policy and Political Change (New Haven, Yale Univ. Press, 1974).

40 Rosenberg, supra n. 20, at 107-156.

41 Michael McCann, Rights at Work: Pay Equity Reform and the Politics of Legal Mobilization (Chicago, Univ. of Chicago Press, 1994) 48-91. 
new rights against discrimination in the work place are systematically neutered in the process of being institutionalized in concrete organizational settings. ${ }^{42}$

More generally, the new institutionalism in economics, political science, and sociology has modified traditional institutional analysis within each of these disciplines in ways that acknowledge a greater role of law. In economics, rational individuals striving to maximize their utility are constrained by institutional settings and structures, often defined by law, that are taken for granted. Politics is more than the resultant of group interests; institutions - namely, law - matter. Similarly the new institutionalism in sociology argues that not everything can be accounted for in terms of social stratification or social structure; institutions - namely, law - matter. In each case, legal institutions and structures have come to be understood as constituting part of the background, the taken-for-granted arrangements in society, around which or through which social objectives are pursued. Although law matters, often significantly, in these new theoretical approaches, law still is not central. In the language of positivism, law is one of the independent variables.

\section{Law as a Distinct Form of Social Ordering}

There is a third way in which law and social science intersect. For some, law is a distinct form of social ordering, one significant enough to warrant a distinct focus as a "field" or "discipline" of its own. The contemporary father of this conception may be Lon Fuller, who argued, persuasively in my view, that law is one of the great and distinct forms of social ordering. ${ }^{43} \mathrm{He}$ maintains that law deserves a place alongside government and the market, as one of three ubiquitous forms' of social ordering. Government, he holds, is the process of achieving social order by binding the wills of the many to the authority of the few through fiat,

42 Lauren Edelman, "Legal Environments and Organizational Governance: The Expansion of Due Process in the workplace" (1990) 95 American J. of Sociology, 1401-1440. See also Bumiller, supra n. 21.

43 His classical statement is in Lon Fuller, "The Forms and Limits of Adjudication" (1978) 92 Harvard L. Rev. 353-409. Mimeographed versions of this manuscript were widely circulated from the mid-1950s, and it was only published posthumously. See also his The Morality of Law (New Haven, Yale Univ. Press, 1969). 
force, or election. The market achieves social order though reciprocity and exchange. Law, Fuller emphasizes, subjects humans to an ordering based on the appeal of reasoned arguments and proofs. Like these other two forms of human ordering, law is universal across time and place. And law not only employs its own distinct set of techniques and practices, it also possesses its own distinct "inner morality." As such, Fuller argues, legality merits special attention to understand its variety of forms and functions. It requires fidelity to process and to principle in ways that distinguish it from exchange and reciprocity based in the market and authority based in politics, both of which ultimately are based upon interests not principle.

Others have developed Fuller's insights. In particular, my colleague, the sociologist Philip Selznick, has elaborated on the distinctive characteristics of law and, perhaps more than any other scholar, has laid the foundations for a distinct field of socio-legal studies. Law or legality, he maintains, is a distinct type of institution, and just as there is a sociology of organizations - or more generally an empirically grounded field of "organization theory" - there should also be a distinct, empirically grounded field of legality. Both Fuller and Selznick have at times been dismissed as trying to re-import natural law theories into a positivist tradition that has finally rid itself of natural law theories of the law. ${ }^{44}$ But Selznick's (and Fuller's) central point is that law is a normative ordering, and his sociology of law is an empirical study of this distinct type of normative ordering.

In several articles and two important books, Selznick set out the agenda for such an enterprise. ${ }^{45} \mathrm{He}$ argues that the central task of the social sciences is to describe and account for variation in social life. Accordingly, the central task of a social science approach to law is to account for two types of variations in legality: 1) the amount or degree of legality that governs particular relationships - expanding legality; and 2) the types and forms of legality.

Donald Black, "Review of Law, Society and Industrial Justice" (1974) 78 American J. of Sociology, 709-714.

45 Philip Selznick, Law, Society and Industrial Justice (New York, Russell Sage Foundation, 1969); Philippe Nonet and Philip Selznick, Law and Society in Transition (New York, Harper Row, 1977). For an assessment of Selznick's work on legal ordering, see Robert A. Kagan, Martin Krygier, and Kenneth Winston, eds., Legality and Community: On the Intellectual Legacy of Philip Selznick (Lanham, MD, Rowman \& Littlefield, 2001). 
Neither Fuller nor Selznick develop a programmatic argument for a separate field of socio-legal studies, but their writings stress the distinctive features of law that set it apart from other forms of social ordering. The programmatic implications are obvious: because law is a universal or near-universal feature of societies, it is a worthy candidate as a distinct field of study. Still other scholars have made similar arguments that also suggest that law is an important and distinct form of social ordering, perhaps distinct enough to merit its own place in the social sciences broadly construed. One loose group of scholars writes in reaction to the problems of modernity and mass society. How, they ask, does a society communicate with itself and make decisions for itself? Rejecting as impractical and romantic much (but not all) in the revival of communitarian thought, they argue instead that law - constitutional law in particular - constitutes a means by which an open society carries on a continuing dialogue and examination of issues. Law, in their formulations, performs a distinct and crucial function in modern mass society. The German social theorist Jurgen Habermas is perhaps the leading exponent of this perspective.$^{46}$ In his voluminous writings about the "theory of communication" in modern mass society, law is featured prominently. American constitutional law scholars have been heavily influenced by his perspective, and argue that constitutional law - and law more generally - is one important means through which a democratic polity communicates with itself. Rejecting a utilitarian conception of law, they argue that law is a means by which a large and complex community gives concrete expression to its core values and occasionally formulates new values. Although work in this vein is often focused on particular settings, the framework is general. The broader implication of this work is that law serves a distinctive, essential, institutional function in modern society.

Sociologist Niklas Luhmann and some of his followers, most particularly legal scholar Gunther Teubner, have developed a related theory. ${ }^{47}$ Reviving and adapting Parsonian systems theory, they see any number

46 Jurgens Habermas, Legitimation Crisis (Boston, Beacon Press, 1970); and Between Facts and Norms: Contributions to a Discourse Theory of Law and Democracy (Studies in Contemporary German Social Thought) (Cambridge, The MIT Press, 1996).

47 N. Luhmann, A Sociological Theory of Law (Longon, Routledge and Kegan Paul, 1985); and "The Unity of the Legal System" in Gunther Teubner, ed., Autopoietic Law: A New Approach to Law and Society (Berlin, de Gruyter, 1988) 12-35. 
of social institutions as "systems" that behave according to their own internal logic. Law, according to them, is one such institution. Law is a system that integrates its various component parts in accordance with its own internal logic - a system of communication. It is, in the words of Teubner, a "self-regulating" system. ${ }^{48}$ As such, law, or more properly the legal system, constitutes a distinct focus or subject of scholarly inquiry. ${ }^{49}$ Still others see in law a distinct form of social ordering. In a single brilliant essay, Robert Cover examined the distinguishing features of law: its simultaneous dependence on "violence and the word," force, and reason. ${ }^{50}$ Since then, others have picked up this theme and made it a central focus in their own study of law. ${ }^{51}$

This brief discussion has reviewed several approaches that suggest that law is distinct enough to merit a separate institutional status in social science and social theory. Although these several traditions are quite different from one another, they share the common belief that law is a central, ubiquitous form of social ordering in society and, as such, merits sustained attention. If I am correct in this assessment, these (and still other) works may constitute the bases for an incipient socio-legal studies field or discipline. This field may do for law what economics does for the market, political science does for politics, psychology does for the personality, and comparative religion does for theology. In each of these areas of inquiry, there is a basic division in research and training; there are those who study the institution as a social phenomenon, and there are those who support the practices of the institution. Thus, for instance, there are departments of economics and business schools and a rough division of labor between them; one theorizes about the nature of economic transactions, and the other supports research that seeks ways to sustain and improve economic activity and institutions. Similarly, there is a rough division of labor between political science and public administration. Perhaps the division of labor is clearest in the study of religion, where programs in comparative religion seek to understand religion in historical and comparative context, while the scholarly en-

48 Gunther Teubner, "Evolution of Autopoietic Law" in G. Teubner, ed., op cit., supra n. 47 , at $217-241$.

49 See also, David Nelken's article in this Symposium.

50 Robert Cover, "Violence and the Word" (1986) 95 Yale Law Journal (1986), 16011629.

51 See, e.g., Austin Sarat, "Every Good Discipline Deserves a Canon, or How Can We Fight if We Are Not Armed?" Law \& Society Newsletter, November 1998, 1-3. 
terprise in schools of theology is to systematize and justify religious doctrine and practice. Similarly, law schools seek to train practitioners and conduct research that improves the law, while the emerging field of socio-legal studies seeks to understand law as it is embedded in the larger society.

The discussion above suggests a clearer division of labor between law-as-practical training and applied scholarship and law-as-scholarly discipline. This should not be surprising. In none of the pairs of fields mentioned above is there a clear separation between theoretical and applied concerns. In each case, the pairs of fields are porous. Abstract and theoretical inquiry takes places in business schools, public administration programs, schools of theology, and law schools, and policydriven research is performed by those in programs of economics, political science, law schools, and comparative religions. Economists train and consult with businesses and are often found in business schools, political scientists train and consult with pubic administrators, and much of the study of religion is undertaken by theologians. Despite this overlap of function, the distinction between practitioner and scholar is relatively clear, and the distinction between adhering to the tenets or even training to adhere to the tenets - exchange in the marketplace, politics, and religious observance - and studying it as a social phenomenon is relatively clear. Although scholars might consult or practice what they study, they also "study" it in ways that make them observers. Thus, for instance, economists develop theories for other economists to consider, political scientists write for other political scientists, and students of comparative religion write for themselves and their colleagues in allied fields and not religious observers or theologians.

The idea I have sketched out above is hardly unique. Any number of people over time have lamented that study about law has not developed into one of the standard arts and science disciplines. Perhaps the most sustained argument in favor of study of law as a distinct enterprise is Paul Kahn's book, The Cultural Study of Law: Reconstructing Legal Scholarship. ${ }^{52}$ Kahn argues that legal scholars are preoccupied with legal reform and criticizes them for this preoccupation. "Legal scholars," he asserts, "are not studying law, they are doing it." 53 Likening law schools to schools of theology, he proposes the establishment of proUniv, of Chicago Press, 1999).

53

Ibid., at 27. 
grams to study law that are akin to programs in comparative religion, efforts that examine "the culture of the rule of law itself as a distinct way of understanding and perceiving meanings in the events of our political and social life. ${ }^{\$ 4}$ The central part of his short book is devoted to setting out an agenda for the new discipline of the cultural study of law. His central message is that law is but one - and perhaps not the most compelling - of several forms of social ordering and that a meaningful cultural analysis of the law must place law alongside these alternative forms of social ordering. Kahn's book is an exciting manifesto for a new discipline of legal studies as a form of cultural studies. Coming as it does from the heights of the citadel (Yale Law School), it is likely to have a significant influence and may help spark the development of, say, true graduate studies in law along the lines he envisions. However, the book has a certain naïveté; it reflects the insular nature of legal scholarship that the author himself seeks to break out of. It is written as if it were a new insight. As discussed above, anthropologists since Maine and sociologists since Durkheim have been pursuing systematic study about law from the sort of cultural perspective he proposes, so it is hardly new. What is new, however, is Kahn's attack on the hegemony of the modern law school with its tendency to orient almost all legal scholarship toward the practical affairs of the law, thereby turning legal scholars toward "doing" law rather than "studying" law. For this reason alone, it stands as an eloquent appeal for a separate field of the cultural study of law.

\section{Conclusion}

The central purpose of this article has been to examine the different voices of socio-legal studies. Legal scholars write for judges in the common law countries and law commissions elsewhere, and social scientists - like scholars more generally - tend to write for each other. But even among socio-legal scholars there are several distinct traditions that lead to their talking past one another. Socio-legal studies speak with different voices to different audiences. In this article I have explored three somewhat distinct voices: the voice of policy science; a separate voice within the various social sciences; and finally, as the voice of a distinct discipline of sociological studies. The first two fields 
are sprawling, and there is considerable overlap between them. The third hardly exists as a field at all. Nevertheless, I do think that each of these enterprises speaks with a distinct and separate voice and addresses its concerns to a distinct, separate audience. In elaborating the nature of each of these three voices, I have tried to offer a few categories and types of work and provide some examples of representative works. But each of the fields is so diverse and diffuse they might reasonably have been divided in any number of different ways. Still, I do think the basic division into three separate efforts and audiences is a useful way of understanding the cacophony of voices in socio-legal studies. Of the three voices, the least developed is, in my view, the most important. It remains to be seen, however, whether a separate sociolegal studies develops into a mature field. 